Б.І. Слонецький', М.І. Тутченко ', І.В. Вербицький ${ }^{2}$ В.О. Коцюбенко ${ }^{1}$ Національний медичний університет імені О.О. Богомольця, Київ ${ }^{2}$ Національна медична академія післядипломної освіти імені П.Л. Шупика, Київ ${ }^{3}$ Київська міська клінічна лікарня швидкої медичної допомоги

\title{
Негативні передумови та прагматичні рішення щодо ургентної хірургії органів черевної порожнини
}

Мета - провести порівняльний аналіз стану ургентної хірургічної допомоги пацієнтам із гострими захворюваннями органів черевної порожнини у м. Київ за період 2000-2019 рр. та намітити основні напрямки вдосконалення надання невідкладної абдомінальної хірургічної допомоги. Об'єкт і методи дослідження: хірургічна служба м. Київ, де у 18 медичних закладах надається ургентна допомога пацієнтам із гострими захворюваннями органів черевної порожнини. Результати. За останні кілька десятиліть чисельність загальних хірургів у м. Київ вірогідно не збільшилася, але спостерігається значне підвищення їх кваліфікаційного рівня, адже кількість фахівців, які не потребують атестації, зменшилася у >2 рази, а кількість лікарів з вищою категорією суттєво зростає та становить більшість. Кількість оперативних втручань на органах травлення та черевної порожнини у Києві зросла з 23503 у 2000 р. до 26114 у 2018 р., однак число ургентних операцій зменшилося з 18500 в 2000 р. до 12984 у 2019 р.

Ключові слова: невідкладна хірургія, оперативні втручання, органи черевної порожнини.

\section{Вступ}

Сучасні вимоги щодо ведення пацієнтів із гострими захворюваннями органів черевної порожнини (ОЧП), які нерідко потребують невідкладного хірургічного втручання, значною мірою пов'язані зі станом фінансування всієї медичної галузі (Burcharth J. et al., 2019; Dobson G.P., 2020). Адже виконання необхідного обсягу ургентного хірургічного втручання в цілодобовому режимі з дотриманням усіх складових світових протоколів та гайдлайнів, з урахуванням індивідуальних особливостей пацієнта потребує необхідного технологічного забезпечення галузі та перебування хворих у сучасних спеціалізованих відділеннях, клініках чи центрах (Полянський І.Ю. та співавт., 2017; Berríos-Torres S.I. et al., 2017). Аналіз даних щодо лікування пацієнтів із гострими захворюваннями ОЧП, що потребують ургентного втручання, дозволяє прогнозувати напрямки розвитку хірургічної галузі, запобігати виникненню ускладнень та застосовувати патогенетично обґрунтовану діагностико-лікувальну тактику в цілодобовому режимі (Усенко О.Ю., 2018; Fang X. et al., 2018).

Мета - провести порівняльний аналіз надання ургентної хірургічної допомоги пацієнтам із гострими захворюваннями ОЧП в м. Київ за період 2000-2019рр. та виявити окремі динамічні негативні тенденції, що дозволить прогнозувати та вдосконалювати надання невідкладної абдомінальної хірургічної допомоги.

\section{Об'єкт і методи дослідження}

Проведено аналіз звітів по м. Київ за період 2000-2019 рр. щодо надання ургентної хірургічної допомоги пацієнтам із гострими захворюваннями ОЧП з урахуванням загальної кількості хірургів загального профілю, їх атестаційного рівня, а також термінів госпіталізації пацієнтів з моменту захворювання та результатів лікування (ДЗ «Центр медичної статистики Міністерства охорони здоров'я України», 2020).

Статистичну обробку даних здійснювали за допомогою методів варіативної статистики на персональному комп'ютері «Pentium ${ }^{\circledast}$ Dual-Core CPU E6500" з використанням програмного забезпечення «Microsoft Office Professional 2013» та «LibreOffice Calc» на базі «Microsoft Windows 10 Pro».

\section{Результати та їх обговорення}

Хірургічна служба у м. Київ є потужною складовою усієї столичної медичної галузі та формує уявлення про неї загалом. Ургентна допомога пацієнтам із гострими захворюваннями ОЧП надається у 18 медичних закладах.
Надання ургентної хірургічної допомоги високого рівня пацієнтам із гострими захворюваннями ОЧП пов'язане з низкою суб'єктивних та об'єктивних чинників, серед яких одне з провідних місць, якщо не головне, займає професійність кадрів. Мабуть, значна розпорошеність закладів, у яких виконують ургентні хірургічні втручання, у більше ніж 3-мільйонному столичному регіоні може ускладнювати необхідну концентрацію лабораторного та інструментального устаткування, чим погіршує формування столичної хірургічної доктрини і не завжди сприяє виконанню малоінвазивних хірургічних втручань на найвищому рівні.

Аналізуючи динамічні процеси серед лікарів-хірургів у м. Київ за останні 20 років, слід відмітити незначне збільшення іх загальної кількості - 3510 загальних хірургів у 2000 р. до 552 - у 2019 р. Зазначимо, що укомплектованість ними хірургічної сфери, на превеликий жаль, становить лише 83\%. Однак кваліфікаційний рівень загальних хірургів у Києві за останні 20 років суттєво покращився: кількість фахівців, які не потребують атестації, зменшилася у >2 рази, а кількість лікарів з вищою категорією суттєво зросла та становила більшість - 331 (табл. 1).

За останні кілька десятиліть у м. Київ кількість оперативних втручань на органах травлення та черевної порожнини дещо збільшилася - з 23503 операцій у 2000 р. до 26114 у 2018 р. $(+11,12 \%)$, однак кількість ургентних операцій на органах травлення та черевної порожнини зменшилася з 18500 в 2000 р. до 12984 у 2019 р. (-29,01\%) (рисунок).

За останні кілька десятиліть у Києві, як і в Україні в цілому, має місце значне зменшення кількості госпіталізованих в стаціонар з приводу гострої кишкової непрохідності $(-26,39 \%)$, гострого апендициту (-42,43\%), перфоративної виразки шлунка та дванадцятипалої кишки $(-36,54 \%)$ з відповідним зменшенням кількості хірургічних операцій у цих групах хворих. Навіть у м. Київ майже кожен 2-й $(57,81 \%)$ пацієнт з гострою кишковою непрохідністю та майже кожен 3-й (30,59\%) - з перфоративною виразкою шлунка та дванадцятипалої кишки госпіталізується пізніше 1-ї доби з моменту захворювання. Привертає увагу значне зниження післяопераційної летальності у кілька разів у пацієнтів із цими захворюваннями (табл. 2).

У м. Київ, на відміну від загальної тенденції в державі, за останні 20 років спостерігали збільшення $(+13,7 \%)$ кількості пацієнтів, що ургентно прооперовані з приводу защемлених вентральних гриж зі зменшенням загальної післяопераційної летальності у 3,16 раза та післяопераційної летальності при пізній госпіталізації у 7,83 раза (табл. 3). 
Таблиця 1. Лікарі-хірурги в комунальних закладах охорони здоров'я м. Київ Кількість Не підлягають Мають кваліфікаційну категорію фізичних осіб атестації Усього Вищу । II

\begin{tabular}{|c|c|c|c|c|c|}
\hline \multicolumn{6}{|c|}{2000 p. } \\
\hline 510 & 214 & 296 & 150 & 95 & 51 \\
\hline \multicolumn{6}{|c|}{2013 p. } \\
\hline 541 & $79\left(p^{* *}\right)$ & $462\left(p^{* *}\right)$ & $280\left(p^{*}\right)$ & 104 & $78\left(p^{*}\right)$ \\
\hline \multicolumn{6}{|c|}{2018 p. } \\
\hline 558 & $90\left(p^{* *}\right)$ & $468\left(p^{* *}\right)$ & $333\left(p^{* *}\right)$ & 89 & 46 \\
\hline \multicolumn{6}{|c|}{2019 p. } \\
\hline 552 & $98\left(p^{* *}\right)$ & $454\left(p^{* *}\right)$ & $331\left(p^{* *}\right)$ & $72\left(p^{*}\right.$ & 51 \\
\hline
\end{tabular}

Коефіцієнт вірогідності $p^{*}<0,05 ; p^{* *}<0,01 ; p-$ вірогідність у порівнянні з $2000 p$.

Таблиця 2. Тенденції госпіталізації та хірургічного лікування в м. Київ пацієнтів із гострою кишковою непрохідністю, гострим апендицитом та перфоративною виразкою у період 2000-2019 рр.

\begin{tabular}{|c|c|c|c|c|c|}
\hline \multicolumn{2}{|c|}{$\begin{array}{c}\text { Гостра кишкова } \\
\text { непрохідність }\end{array}$} & \multicolumn{2}{|c|}{ Гострий апендицит } & \multicolumn{2}{|c|}{$\begin{array}{c}\text { Перфоративна виразка } \\
\text { шлунка та дванадцяти- } \\
\text { палої кишки }\end{array}$} \\
\hline 2000 p. & 2019 p. & 2000 p. & $2019 \mathrm{p}$. & $2000 \mathrm{p}$. & 2019 p. \\
\hline \multicolumn{6}{|c|}{ Доставлено в стаціонар } \\
\hline 557 & $410\left(p^{* *}\right)$ & 8832 & $5085\left(p^{* *}\right)$ & 614 & $389\left(p^{* *}\right)$ \\
\hline \multicolumn{6}{|c|}{ Доставлено в стаціонар пізніше ніж через 24 год } \\
\hline 264 & 237 & 2905 & $1532\left(p^{* *}\right)$ & 124 & 119 \\
\hline \multicolumn{6}{|c|}{ Кількість операцій } \\
\hline 512 & $388\left(p^{\star}\right)$ & 8830 & $5066\left(p^{*+}\right)$ & 607 & $383\left(p^{* *}\right)$ \\
\hline \multicolumn{6}{|c|}{ Післяопераційна летальність (\%) } \\
\hline 7,0 & $4,64\left(p^{* *}\right)$ & 0,0 & 0,00 & 4,9 & $3,66\left(p^{*}\right)$ \\
\hline \multicolumn{6}{|c|}{ Післяопераційна летальність при госпіталізації через понад 24 год (\%) } \\
\hline 10,6 & $6,44\left(p^{* *}\right)$ & 0,0 & 0,00 & 19,5 & $7,08\left(p^{* *}\right)$ \\
\hline
\end{tabular}

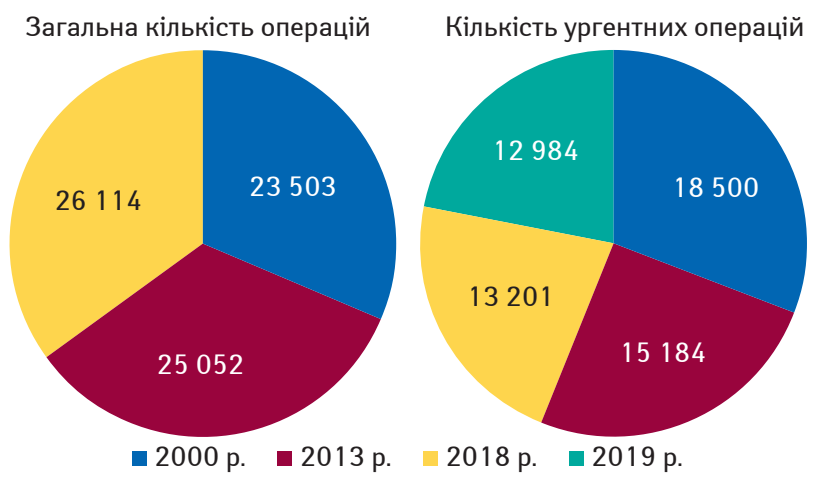

Рисунок. Кількість оперативних втручань у пацієнтів на органах травлення та черевної порожнини, що виконані у м.Київ

Таблиця 3. Тенденції щодо госпіталізації та хірургічного лікування у м.Київ пацієнтів із защемленою грижою, гострим холециститом, гострим панкреатитом за період 2000-2019 рр.

\begin{tabular}{|c|c|c|c|c|c|}
\hline \multicolumn{2}{|c|}{ Защемлена грижа } & \multicolumn{2}{|c|}{ Гострий холецистит } & \multicolumn{2}{|c|}{ Гострий панкреатит } \\
\hline $2000 \mathrm{p}$. & 2019 p. & 2000 p. & $2019 p$. & 2000 p. & 2019 p. \\
\hline \multicolumn{6}{|c|}{ Доставлено в стаціонар } \\
\hline 774 & $877\left(p^{*}\right)$ & 2029 & $1824\left(p^{*}\right)$ & 2508 & $1602\left(p^{* *}\right)$ \\
\hline \multicolumn{6}{|c|}{ Доставлено в стаціонар пізніше ніж через 24 год } \\
\hline 187 & $291\left(p^{*}\right)$ & 1166 & $900\left(p^{*}\right)$ & 1208 & $770\left(p^{\star \star}\right)$ \\
\hline \multicolumn{6}{|c|}{ Кількість операцій } \\
\hline 771 & 877 & 1486 & $1697\left(p^{*}\right)$ & 174 & 206 \\
\hline \multicolumn{6}{|c|}{ Післяопераційна летальність (\%) } \\
\hline 1,8 & $0,57\left(p^{* *}\right)$ & 1,2 & $0,35\left(p^{* *}\right)$ & 15,5 & 15,05 \\
\hline \multicolumn{6}{|c|}{ Післяопераційна летальність при госпіталізації через понад 24 год (\%) } \\
\hline 5,4 & $0,69\left(p^{* *}\right)$ & 1,6 & $0,59\left(p^{* *}\right)$ & 22,1 & 19,39 \\
\hline
\end{tabular}

Таблиця 4. Тенденції щодо госпіталізації та хірургічного лікування в м.Київ пацієнтів із шлунково-кишковими кровотечами

\begin{tabular}{lcccc}
\hline \multicolumn{1}{c}{ Критерій } & \multicolumn{4}{c}{ Термін спостереження } \\
\cline { 2 - 5 } & $\mathbf{2 0 0 0}$ p. & $\mathbf{2 0 1 3}$ p. & $\mathbf{2 0 1 8}$ p. & $\mathbf{2 0 1 9}$ p. \\
\hline Доставлено в стаціонар & 1500 & 1473 & $\begin{array}{c}1733 \\
\left(p^{*}\right)\end{array}$ & 1598 \\
Доставлено в стаціонар пізніше 24 год & 621 & 664 & 718 & 493 \\
& & & & $\left(p^{*}\right)$ \\
Кількість операцій & 224 & 86 & 84 & 98 \\
& & $\left(p^{* *}\right)$ & $\left(p^{* *}\right)$ & $\left(p^{* *}\right)$ \\
Післяопераційна летальність (\%) & 3.1 & 15,12 & 5,95 & 5,10 \\
& & $\left(p^{* *}\right)$ & $\left(p^{* *}\right)$ & $\left(p^{*}\right)$ \\
Післяопераційна летальність при госпіта- & 5.3 & 14,28 & 2,71 & 3,33 \\
лізації через понад 24 год (\%) & & $\left(p^{* *}\right)$ & $\left(p^{* *}\right)$ & $\left(p^{* *}\right)$ \\
\hline
\end{tabular}

У період 2000-2019 рр. у м. Київ також спостерігали зменшення кількості хворих, госпіталізованих з приводу гострого холециститу, але кількість прооперованих пацієнтів зросла на 14,9\% зі значним зниженням післяопераційної летальності. Щодо пацієнтів із гострим панкреатитом відмічається суттєве зменшення їх кількості - на 36, 13\%. І хоча кількість операцій збільшилася на 18,39\%, суттєвого зниження післяопераційної летальності не виявлено.

Аналіз тенденцій щодо госпіталізації та хірургічного лікування в м. Київ пацієнтів із шлунково-кишковими кровотечами (табл. 4) не виявив особливих змін: майже кожного 2-го госпіталізовано пізніше ніж через 24 год з моменту захворювання. У 2019 р. кількість оперативних втручань зменшилася до 98 серед 1598 госпіталізованих, але післяопераційна летальність внаслідок хірургічного лікування пацієнтів із шлунково-кишковими кровотечами у порівняні з 2000 р. підвищилася у 1,64 раза.

Сучасна доктрина розвитку ургентної хірургії полягає у широкому використанні уніфікованих інструментів прогнозування, які ґрунтуються на аналізі великих проспективних досліджень і дозволяють лікарям приймати більш зважені клінічні рішення з урахуванням індивідуальних особливостей пацієнтів (Фомін П.Д., Матвійчук O.Б., 2017; Nally D.M. et al., 2019). Саме тому застосування різноманітних систем прогнозування та оцінки моніторингу ефективності вибраних протоколів чи алгоритмів надання патогенетично обґрунтованої хірургічної допомоги сприятиме оптимізації лікувального процесу і суттєвому скороченню реабілітаційного етапу.

\section{Висновки}

1.За останні кілька десятиліть чисельність загальних хірургів у м.Київ не збільшилася, але спостерігається значне підвищення їх кваліфікаційного рівня, адже кількість фахівців, які не потребують атестації, зменшилася у >2 рази, а кількість лікарів з вищою категорією суттєво зростає та становить більшість.

2. Кількість оперативних втручань на органах травлення та черевної порожнини у м. Київ зросла з 23503 у 2000 р. до 26114 у 2018 р. (+11,12\%), однак кількість ургентних операцій на ОЧП зменшилася з 18500 в 2000 р. до 12984 (-29,01\%) у 2019 р.

\section{Конфлікт інтересів}

Автори заявляють про відсутність конфлікту інтересів під час підготовки статті.

\section{Список використаної літератури}

Д3 «Центр медичної статистики Міністерства охорони здоров'я України" (2020) Статистичні дані системи М03 за 2019 рік. Форма № 17 «Звіт про медичні кадри за рік» (http://medstat.gov.ua/ukr/statdan.html).

Полянський І.Ю., Мороз П.В., Москалюк В.І. та ін. (2017) Лікування перитоніту - шлях від доказової до персоналізованої медицини. Харківська хірургічна школа, 1(82): 59-63.

Усенко О.Ю. (2018) Матеріали XXIV з'їзду хірургів України. Зб. наук. робіт, Клін. хірургія, Київ, 596 с.

Фомін П.Д., Матвійчук О.Б. (2017) Третинний перитоніт як проблема абдомінальної хірургії. Клін. хір., 2(908): 77-79.

Berrios-Torres S.I., Umscheid C.A., Bratzler D.W. et al.; Healthcare Infection Control Practices Advisory Committee (2017) Centers for Disease Control and Prevention Guideline for the Prevention of Surgical Site Infection, 2017. JAMA Surg., 152(8): 784-791. doi: 10.1001/jamasurg.2017.0904.

Burcharth J., Abdulhady L., Danker J. et al. (2019) Implementation of a multidisciplinary perioperative protocol in major emergency abdominal surgery. Eur. J. Trauma Emerg. Surg., Oct. 18 [Online ahead of print]. DOI: 10.1007/s00068-019-01238-7.

Dobson G.P. (2020) Trauma of major surgery: a global problem that is not going away. Int. J Surg., 81: 47-54. doi: 10.1016/ j.ijsu.2020.07.017.

Fang X., Wang Zh., Yang J. et al. (2018) Clinical Evaluation of Sepsis-1 and Sepsis-3 in the ICU. Chest, 153(5): 1169-1176.

Nally D.M., Sørensen J., Valentelyte G. et al. (2019) Volume and inhospital mortal-ity after emergency abdominal surgery: a national population-based study. BMJ Open, 9(11): e032183. doi: 10.1136/bmjopen-2019-032183.

\section{Негативные предпосылки}

\section{и прагматичные решения в ургентной хирургии органов брюшной полости}

Б.И. Слонецкий, М.И. Тутченко, И.В. Вербицкий, В.О. Коцюбенко

Резюме. Цель - провести сравнительный анализ состояния ургентной хирургической помощи пациентам с острыми заболеваниями органов брюшной полости в г. Киев в период 2000-2019 гг. и наметить основ- 
ные направления совершенствования оказания неотложной абдоминальной хирургической помощи. Объект и методы исследования: хирургическая служба г. Киева, где в 18 медицинских учреждениях оказывается ургентная помощь пациентам с острыми заболеваниями органов брюшной полости. Результаты. В последние несколько деся тилетий численность общих хирургов в Г. Киев достоверно не увеличилась, но отмечается значительное повышение их квалификацион ного уровня: число специалистов, не требующих аттестации, уменьшилось в >2 раза, а количество врачей с высшей категорией существенно возросло и составило большинство. Количество оперативных вмешательств на органах пищеварения и брюшной полости в Киеве выросло с 23503 в 2000 г. до 26114 в 2018 г., однако число ургентных операций уменьшилось с 18500 в 2000 г. до 12984 в 2019 г.

Ключевые слова: неотложная хирургия, оперативные вмешательства, органы брюшной полости.

\section{Negative prerequisites and pragmatic decisions in emergency abdominal surgery \\ B.I. Slonetsky, M.I. Tutchenko, I.V. Verbitsky, V.O. Kotsyubenko}

Summary. The aim is to conduct a comparative analysis of emergency abdominal surgery in the city of Kyiv from 2000 to 2019 and to outline the main directions for improving the provision of emergency abdominal surgery. Object and methods of research: surgical service of the city of Kyiv, where in 18 medical institutions urgent care is provided to patients with acute diseases of the abdominal cavity. Results. Over the last few decades, the number of general surgeons in Kyiv has probably not increased, but there is an increase in their skills, because the number of specialists who do not require certification has decreased more than 2 times, and the number of doctors with the highest category has increased significantly and made up the majority. The number of gastrointestinal and abdominal surgeries in Kyiv increased slightly from 23,503 in 2000 to 26,114 in 2018, but the number of urgent operations decreased from 18,500 in 2000 to 12,984 in 2019

Key words: emergency surgery, surgical interventions, abdominal organs.

Адреса для листування:

Вербицький Ігор Володимирович

04112, Київ, вул. Дорогожицька, 9

Національна медична академія післядипломної освіти імені П.Л. Шупика, кафедра медицини невідкладних станів

E-mail: ukrpodol@gmail.com 